\title{
PENGARUH PEMATAHAN DORMANSI SECARA KIMIAWI TERHADAP KEMAMPUAN BERKECAMBAH BENIH HANJELI (Coix Lacryma-jobi L.)
}

\author{
Dormancy Breaking Effect by Chemical on \\ Germination Ability of Seeds Job's Tears (Coix \\ Lacryma-jobi L.) \\ Rama Adi Pratama ${ }^{1}$ \\ ${ }^{1}$ Program Studi Agroteknologi Fakultas Pertanian Universitas \\ Garut \\ E-mail : ramatarigan21@gmail.com
}

\begin{abstract}
Abstrak
Tanaman hanjeli (Coix lacryma-jobi) merupakan tanaman yang memiliki kandungan karbohidrat, protein dan lemak. Tujuan penelitian ini adalah mengetahui pematahan dormansi secara kimiawi terhadap kemampuan perkecambahan benih hanjeli. Penelitian ini dilaksanakan di Laboratorium Fakultas Pertanian Universitas Garut pada Agustus 2016 menggunakan Rancangan Acak Lengkap dengan satu faktor perlakuan pematahan dormansi secara kimiawi yaitu perendaman dengan larutan $\mathrm{H}_{2} \mathrm{SO}_{4}$. Terdapat 6 perlakuan dan diulang sebanyak 3 kali. Perlakuan terdiri dari $\mathrm{A}_{0}$ (kontrol), $\mathrm{A}_{1}\left(\mathrm{H}_{2} \mathrm{SO}_{4} 1 \%\right), \mathrm{A}_{2}\left(\mathrm{H}_{2} \mathrm{SO}_{4}\right.$ $2 \%), \mathrm{A}_{3}\left(\mathrm{H}_{2} \mathrm{SO}_{4} 3 \%\right), \mathrm{A}_{4}\left(\mathrm{H}_{2} \mathrm{SO}_{4} 4 \%\right), \mathrm{A}_{5}\left(\mathrm{H}_{2} \mathrm{SO}_{4} \%\right)$. Parameter yang diamati adalah daya berkecambah, potensi tumbuh maksimum, kecepatan tumbuh dan intensitas dormansi. Hasil penelitian menunjukkan bahwa pematahan dormansi secara kimiawi yaitu perendaman dengan larutan $\mathrm{H}_{2} \mathrm{SO}_{4}$ memberikan pengaruh terhadap daya berkecambah, potensi tumbuh maksimum, kecepatan tumbuh dan intensitas dormansi.
\end{abstract}

Kata Kunci: hanjeli, dormansi, daya berkecambah

\section{Abstract}

Jobs Tears (Coix lacyma-jobi) is a plant that contains carbohydrates, protein and fat. The purpose of this study was to determine the chemical dormancy breaking the seed germination ability Jobs tears. This research was conducted at the Laboratory of the Faculty of Agriculture, University of Garut in August 2016 using a completely randomized design with one factor dormancy 
breaking chemical treatment is soaking with $\mathrm{H} 2 \mathrm{SO} 4$ solution. There are 6 treatment and repeated 3 times. The treatment consisted of $A$ (control), B (H2SO4 1\%). C (H2SO4 2\%), D (H2SO4 3\%), E (4\% H2SO4), F (H2SO4 5\%). Parameters measured were germination capacity (\%), growth potential maximum (\%), germination speed (\%/etmal) and dormancy intencity. The results showed that the dormancy breaking chemical that is soaking with a solution of $\mathrm{H} 2 \mathrm{SO} 4$ to give effect to germination, growth potential maximum, speed of growth and the intensity of dormancy.

Keywords: job's tears, dormancy, germination

PENDAHULUAN

Tanaman hanjeli (Coix lacryma-jobi) merupakan tanaman yang biasa tumbuh secara liar. Hanjeli biasa ditanam sebagai tanaman pagar di lahan tegalan. Hanjeli dapat digunakan sebagai pakan ternak ataupun menjadi tanaman pangan karena mengandung karbohidrat protein dan lemak. Hanjeli memiliki nilai gizi yang baik kandungan karbohidratnya mencapai $76,40 \%$ dan protein yang tinggi yaitu $14,10 \%$ (Gruben dan Partohardjono, 1996). Kulit biji yang dimiliki oleh tanaman hanjeli termasuk keras sehingga sering kali mengalami dormansi. Tingkat dormansi dari setiap benih berbeda dari setiap spesies tanaman. Metode yang digunakan untuk pematahan dormansi pun berbeda tergantung dari faktor mempengaruhinya. Menurut Sutopo (2012) dormansi benih dapat diakibatkan dari keadaan fisik kulit biji, keadaan fisiologis dari embrio atau kombinasi dari kedua keadaan tersebut. Dormansi dapat dipatahkan baik secara fisik, mekanis maupun kimiawi. Perlakuan yang dapat diberikan dalam penanganan dormansi benih yaitu dengan melakukan baik cara mekanis seperti penipisan kulit dengan diasah maupun digosok, peretakan dan sebagainya maupun perlakuan secara kimiawi seperti pemberian larutan asam sulfat dan zat kimia lainnya yang dapat melunakkan kulit biji sehingga dormansi dapat diatasi kemudian benih dapat berkecambah (Yuniarti et al., 2013) .

Pematahan dormansi secara kimiawi dapat dilakukan dengan melakukan perendaman 


\begin{abstract}
dengan larutan $\mathrm{H}_{2} \mathrm{SO}_{4}$. Menurut Fahmi (2012) pemberian skarifikasi kimia bertujuan untuk membuat kulit benih lebih mudah dimasuki air ketika imbibisi. Perendaman larutan kimia yaitu golongan asam kuat seperti $\mathrm{H}_{2} \mathrm{SO}_{4}, \mathrm{KNO}_{3}$ dan $\mathrm{HCl}$ yang mampu membuat kulit benih menjadi lebih lunak sehingga dapat dilalui oleh air dengan mudah. Informasi mengenai pematahan dormansi secara kimiawi terhadap benih hanjeli dengan menggunakan larutan $\mathrm{H}_{2} \mathrm{SO}_{4}$ dibutuhkan untuk pengujian viabilitas benih guna menghasilkan benih hanjeli yang bermutu tinggi. Oleh karena itu dilakukan penelitian tentang pengaruh pematahan dormansi secara kimia terhadap viabilitas benih hanjeli.
\end{abstract}

\section{METODOLOGI}

$\begin{array}{lr}\text { Lokasi dan } & \text { Waktu } \\ \text { Penelitian } & \text { Penelitian } \\ \text { dilaksanakan } & \text { ini } \\ \text { di }\end{array}$

Laboratorium Fakultas

Pertanian Universitas Garut pada Agustus 2016. Lokasi penelitian berada pada ketinggian 766 mdpl.

\section{Alat dan Bahan}

Bahan yang digunakan dari penelitian ini yaitu benih hanjeli, larutan

$\mathrm{H}_{2} \mathrm{SO}_{4}$, kertas merang, air. Alat yang digunakan dalam penelitian ini yaitu beaker glass, gelas ukur, handsprayer.

\section{Metodologi Penelitian}

Penelitian menggunakan Rancangan Acak Lengkap dengan enam perlakuan dan diulang sebanyak tiga kali yaitu : $A_{1}$ (kontrol), $\mathrm{A}_{2}\left(\mathrm{H}_{2} \mathrm{SO}_{4} 1 \%\right) . \mathrm{A}_{3}$ $\left(\mathrm{H}_{2} \mathrm{SO}_{4} 2 \%\right), \mathrm{A}_{4}\left(\mathrm{H}_{2} \mathrm{SO}_{4} 3 \%\right)$, $\mathrm{A}_{5}\left(\mathrm{H}_{2} \mathrm{SO}_{4} 4 \%\right), \mathrm{A}_{6}\left(\mathrm{H}_{2} \mathrm{SO}_{4}\right.$ $5 \%)$. Perlakuan perendaman dengan larutan $\mathrm{H}_{2} \mathrm{SO}_{4}$ selama 1 jam kemudian dilakukan pengujian dengan menggunakan metode UAK (Uji Antar Kertas) menggunakan kertas merang. Parameter yang diamati yaitu daya berkecambah, potensi tumbuh maksimum, kecepatan tumbuh dan intensitas dormansi.

\section{HASIL PEMBAHASAN}

DAN

Berdasarkan hasil
pengamatan dan sidik
ragam daya berkecambah
diketahui bahwa perlakuan
pematahan dormansi secara
kimia berpengaruh nyata
terhadap
daya
perkecambah.
dormanatans
terhadap daya kecambah
terdapat pada Tabel 1.




\begin{tabular}{|c|c|}
\hline $\begin{array}{l}\text { Tabel } 1 \\
\text { Pematahan } \\
\text { secara Kim } \\
\text { Daya Berkec }\end{array}$ & $\begin{array}{l}\text { Pengaruh } \\
\text { Dormansi } \\
\text { lawi terhadap } \\
\text { ambah. }\end{array}$ \\
\hline Perlakuan & $\begin{array}{c}\text { Daya } \\
\text { Berkecambah } \\
(\%)\end{array}$ \\
\hline$A_{0}$ (Kontrol) & $25.33 a$ \\
\hline $\begin{array}{c}\mathrm{A}_{1}\left(\mathrm{H}_{2} \mathrm{SO}_{4}\right. \\
1 \%)\end{array}$ & $29.33 \mathrm{a}$ \\
\hline $\begin{array}{c}\mathrm{A}_{2}\left(\mathrm{H}_{2} \mathrm{SO}_{4}\right. \\
2 \%)\end{array}$ & $40.00 \mathrm{~b}$ \\
\hline $\begin{array}{c}\mathrm{A}_{3}\left(\mathrm{H}_{2} \mathrm{SO}_{4}\right. \\
3 \%)\end{array}$ & $57.33 \mathrm{c}$ \\
\hline $\begin{array}{c}\mathrm{A}_{4}\left(\underset{4 \%)}{\left(\mathrm{H}_{2} \mathrm{SO}_{4}\right.}\right. \\
\text { (1) }\end{array}$ & $58.66 \mathrm{c}$ \\
\hline $\begin{array}{c}\mathrm{A}_{5}\left(\mathrm{H}_{2} \mathrm{SO}_{4}\right. \\
5 \%)\end{array}$ & $80.00 \mathrm{~d}$ \\
\hline
\end{tabular}

Keterangan: Angka yang diikuti notasi yang sama pada setiap baris menunjukkan tidak berbeda nyata denga uji jarak berganda Duncan taraf 5\%.

Tabel 1. menjelaskan daya kecambah tertinggi terdapat pada perlakuan perendaman $\mathrm{H}_{2} \mathrm{SO}_{4} \%\left(\mathrm{~A}_{5}\right)$ sebesar $\quad 80 \% \quad$ bila dibandingkan dengan perlakuan kontrol $\left(\mathrm{A}_{0}\right)$ hanya 25,33\%. Hal ini menunjukkan bahwa penggunaan $\mathrm{H}_{2} \mathrm{SO}_{4}$ mampu melunakkan kulit biji hanjeli dengan kadar tertentu sehingga benih dapat melakukan proses imbibisi. Menurut Sadjad et al., (1975) pemberian $\mathrm{H}_{2} \mathrm{SO}_{4}$ memiliki prinsip membuang lapisan lignin pada kulit biji yang keras dan tebal membuat biji kehilangan

lapisan permiabel terhadap gas dan air sehingga lapisan sehingga metabolisme dapat berjalan baik.

\begin{tabular}{|c|c|}
\hline $\begin{array}{l}\text { Tabel } \\
\text { Pematahan } \\
\text { secara Kir } \\
\text { Potensi Tum }\end{array}$ & $\begin{array}{l}\text { Pengaruh } \\
\text { Dormansi } \\
\text { wi terhadap } \\
\text { hi Maksimum. }\end{array}$ \\
\hline Perlakuan & $\begin{array}{c}\text { Potensi } \\
\text { Tumbuh } \\
\text { Maksimum }\end{array}$ \\
\hline $\mathrm{A}_{0}$ (Kontrol) & $30.66 \mathrm{a}$ \\
\hline $\begin{array}{c}\mathrm{A}_{1}\left(\mathrm{H}_{2} \mathrm{SO}_{4}\right. \\
1 \%)\end{array}$ & $40.00 \mathrm{ab}$ \\
\hline $\begin{array}{c}\mathrm{A}_{2}\left(\mathrm{H}_{2} \mathrm{SO}_{4}\right. \\
2 \%)\end{array}$ & $49.33 \mathrm{~b}$ \\
\hline $\begin{array}{c}\mathrm{A}_{3}\left(\mathrm{H}_{2} \mathrm{SO}_{4}\right. \\
3 \%)\end{array}$ & $70.66 \mathrm{c}$ \\
\hline $\begin{array}{c}\mathrm{A}_{4}\left(\mathrm{H}_{2} \mathrm{SO}_{4}\right. \\
4 \%)\end{array}$ & $74.66 \mathrm{c}$ \\
\hline $\begin{array}{c}\mathrm{A}_{5}\left(\mathrm{H}_{2} \mathrm{SO}_{4}\right. \\
5 \%)\end{array}$ & $85.33 d$ \\
\hline $\begin{array}{l}\text { Keterangan } \\
\text { diikuti not } \\
\text { pada }\end{array}$ & $\begin{array}{ll}\text { ngka } & \text { yang } \\
\text { lang } & \text { sama } \\
0 & \text { baris }\end{array}$ \\
\hline
\end{tabular}
menunjukkan tidak berbeda nyata denga uji jarak berganda Duncan taraf 5\%.

Berdasarkan hasil
pengamatan dan sidik
ragam potensi tumbuh
maksimum diketahui bahwa
perlakuan pematahan
dormansi secara kimia
berpengaruh nyata terhadap
potensi tumbuh maksimum.
Rataan pengaruh
pematahan dormansi secara
kimiawi terhadap potensi
tumbuh maksimum pada
Tabel 2.


Tabel 2. menjelaskan potensi tumbuh maksimum tertinggi terdapat pada perlakuan perendaman $\mathrm{H}_{2} \mathrm{SO}_{4} \quad 5 \% \quad\left(\mathrm{~A}_{5}\right) \quad$ sebesar $85,33 \%$ dan terendah pada perlakuan kontrol $\left(\mathrm{A}_{0}\right)$ hanya $30,66 \%$. $\mathrm{Hal}$ ini menunjukkan bahan kimia seperti larutan $\mathrm{H}_{2} \mathrm{SO}_{4}$ dengan kadar yang lebih tinggi mampu memberikan potensi tumbuh maksimum yang lebih tinggi dibandingkan perlakuan lainnya.

Tabel 3. Pengaruh Pematahan Dormansi secara Kimiawi terhadap Kecepatan Tumbuh.

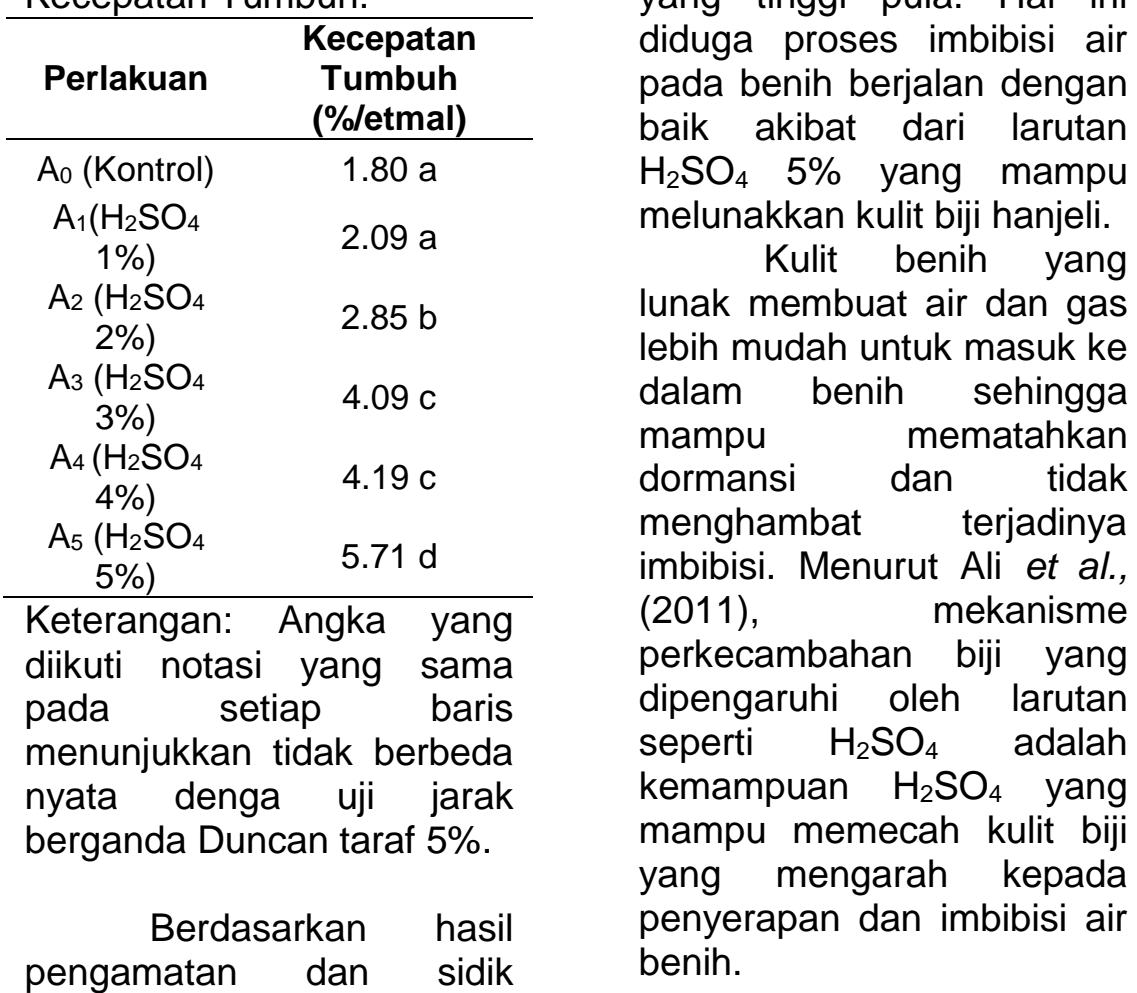

ragam daya berkecambah diketahui bahwa perlakuan pematahan dormansi secara kimia berpengaruh nyata terhadap kecepatan tumbuh. Rataan pengaruh pematahan dormansi secara kimiawi terhadap daya kecambah terdapat pada Tabel 3.

Tabel 3. menjelaskan kecepatan tumbuh tertinggi terdapat pada perlakuan perendaman $\mathrm{H}_{2} \mathrm{SO}_{4} 5 \%\left(\mathrm{~A}_{5}\right)$ sebesar $5,71 \% /$ etmal dan terendah pada perlakuan kontrol $\left(\mathrm{A}_{0}\right)$ hanya 1,80\%/etmal. Kecepatan tumbuh yang tinggi selaras dengan daya berkecambah yang tinggi pula. Hal ini diduga proses imbibisi air pada benih berjalan dengan baik akibat dari larutan $\mathrm{H}_{2} \mathrm{SO}_{4} \quad 5 \%$ yang mampu Kulit benih yang lunak membuat air dan gas lebih mudah untuk masuk ke dalam benih sehingga mematahkan dormansi dan tidak menghambat terjadinya imbibisi. Menurut Ali et al., mekanisme perkecambahan biji yang dipengaruhi oleh larutan seperti $\mathrm{H}_{2} \mathrm{SO}_{4}$ adalah kemampuan $\mathrm{H}_{2} \mathrm{SO}_{4}$ yang mampu memecah kulit biji penyerapan dan imbibisi air 


\begin{tabular}{|c|c|}
\hline $\begin{array}{l}\text { Tabel } 4 . \\
\text { Pematahan } \\
\text { secara Kimiawi } \\
\text { Kecepatan Tumb }\end{array}$ & $\begin{array}{l}\text { Pengaruh } \\
\text { Dormansi } \\
\text { terhadap } \\
\text { uh. }\end{array}$ \\
\hline Perlakuan & $\begin{array}{c}\text { Intensitas } \\
\text { Dormansi } \\
(\%)\end{array}$ \\
\hline$A_{0}$ (Kontrol) & $69.33 d$ \\
\hline $\mathrm{A}_{1}\left(\mathrm{H}_{2} \mathrm{SO}_{4} 1 \%\right)$ & $60.00 \mathrm{~cd}$ \\
\hline $\mathrm{A}_{2}\left(\mathrm{H}_{2} \mathrm{SO}_{4} 2 \%\right)$ & $50.66 \mathrm{c}$ \\
\hline $\mathrm{A}_{3}\left(\mathrm{H}_{2} \mathrm{SO}_{4} 3 \%\right)$ & $29.33 b$ \\
\hline $\mathrm{A}_{4}\left(\mathrm{H}_{2} \mathrm{SO}_{4} 4 \%\right)$ & $25.33 \mathrm{~b}$ \\
\hline $\mathrm{A}_{5}\left(\mathrm{H}_{2} \mathrm{SO}_{4} 5 \%\right)$ & $14.66 \mathrm{a}$ \\
\hline $\begin{array}{l}\text { Keterangan: An } \\
\text { diikuti notasi yciap } \\
\text { pada setiap } \\
\text { menunjukkan tida } \\
\text { nyata denga } \\
\text { berganda Duncan }\end{array}$ & $\begin{array}{l}\text { igka yang } \\
\text { ang sama } \\
\text { baris } \\
\text { ak berbeda } \\
\text { uji jarak } \\
\text { taraf } 5 \% \text {. }\end{array}$ \\
\hline
\end{tabular}

Berdasarkan hasil
pengamatan dan sidik
ragam daya berkecambah
diketahui bahwa perlakuan
pematahan dormansi secara
kimia berpengaruh nyata
terhadap intensitas
dormansi. Rataan pengaruh
pematahan dormansi secara
kimiawi terhadap intensitas
dormansi terdapat pada
Tabel 4.

Tabel 4. menjelaskan intensitas dormansi tertinggi terdapat pada kontrol $\left(\mathrm{A}_{0}\right)$ sebesar $69,33 \%$ bila dibandingkan dengan perlakuan perendaman $\mathrm{H}_{2} \mathrm{SO}_{4} 5 \%$ hanya $14,66 \%$. Intensitas dormansi selaras dengan daya berkecambah. Intensitas dormansi pada perlakuan $\quad \mathrm{H}_{2} \mathrm{SO}_{4} \quad 5 \%$ memiliki nilai yang rendah yaitu $14,66 \%$ sehingga daya berkecambahnya tinggi. Sebaliknya pada perlakuan kontrol $\left(A_{0}\right)$ memiliki intensitas dormansi yang tinggi yaitu 69,33\% sehingga memiliki daya berkecambah yang rendah.

\section{KESIMPULAN}

penelitian

Berdasarkan hasil pematahan dormansi secara kimiawi terhadap tanaman hanjeli dapat disimpulkan bahwa perlakuan perendaman larutan $\mathrm{H}_{2} \mathrm{SO}_{4}$ memberikan pengaruh yang nyata terhadap daya berkecambah, potensi tumbuh maksimum, kecepatan tumbuh dan intensitas dormansi. Perendaman dengan larutan $\mathrm{H}_{2} \mathrm{SO}_{4} \%\left(\mathrm{~A}_{5}\right)$ memberikan nilai yang lebih tinggi terhadap daya berkecambah yaitu $80 \%$, potensi tumbuh maksimum yaitu $85,33 \%$, kecepatan tumbuh yaitu $5,71 \% /$ etmal serta memiliki nilai intensitas domansi yang lebih rendah yaitu $14,66 \%$ dibandingkan dengan kontrol. 
DAFTAR PUSTAKA

Ali, H. H., H. Tanveer., M. A. Nadeem., and $\mathrm{H}$. N. Asghar. 2011. Scientific Note: Methods to Break Seed Dormancy of Rhynchosia capitata a Summer Annual Weed. Chilean Journal of Agicultural Research Vol.71(3).

Fahmi, Z. I. 2012. Studi Perlakuan Pematahan Dormansi Benih Dengan Skarifikasi Mekanik dan Kimiawi. J.Balai Besar Perbenihan dan Proteksi Tanaman Perkebunan Surabaya. hlm:3.

Gruben, G. J. H., dan S. Partohardjono. 1996. Plant Resource of South - East Asia. Bogor.

Sadjad S., S.Hari, S.H.Sri, S.Jusup, H. Sugihdan Sudarsono. 1975. Dasar- Dasar Teknologi Benih. Biro Penataran. Institut Pertanian Bogor. Bogor.

Sutopo, L. 2012. Teknologi Benih. Rajawali Pers. Jakarta.

Yuniarti, N., Megawati dan Budi L. 2013. Teknik Pendahuluan dan Metode perkecambahan untuk
Mempertahankan

Viabilitas benih Acacia crassicarpa Hasil

Pemuliaan. Jurnal penelitian Kehutanan Wallacea. Vol.2 (1): 111. 